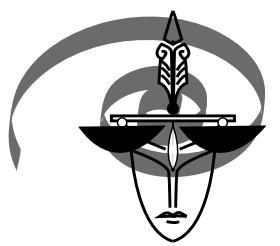

EUROPEAN

Volume $10 \cdot 2016 \cdot$ Number 4 (38)

DOI: 10.1515/ep-2016-0020

Tuvya T. Amsel*

Tel Aviv

Israel

\title{
Polygraph Examinations Contaminating Factors
}

Факторы искажающие полиграфические исследования

Key words: Contaminating factors, polygraph examinations

A box containing expensive medication went missing from a pharmaceutical manufacturer's warehouse. Five stockmen who had access to the box were sent to take a polygraph test. Jim the senior stockman was the least probable suspect for several reasons: he was a devoted and loyal employee, he had no visible motives to steal and he was absent on the day of the theft. In the test he was fully cooperative and his behavior symptoms displayed veracity. Although he was truthful and in spite of very effective comparison questions, his charts were inconsistent and erratic, which led to borderline charts with a strong tendency toward deception. While reasons such as excessive interrogation prior to the test, examinee's excessive concern over the outcome, etc. might have been the reasons behind the results, what emerges as the leading

*ta@amsel.co.il 
cause is mental contamination. Contamination as such is defined as the presence of a minor and unwanted constituent in another substance. To put it in plain English: something concerning the investigated issue is bothering the examinee. The probable polluting agent in our case is the examinee's concern that the test will expose another wrongdoing he committed or he feels responsible for what happened (guilty feeling or complex).

Contamination may be found in all types of examinations, from pre-employment tests when the candidate fears detection of a past misdeed, through periodical screening, where the examinee fears that a minor lie will be revealed, all the way to almost any specific test, where the examinee fears detection of a similar violation he performed in the past.

Contaminations factors can roughly be divided into: Cognitive i.e. thoughts, emotional and physical, as well as into pretest and in-test factors (A list of common contamination factors can be found at the end of this article)

The idea of contamination goes back to the early days of polygraphy. Trovillo [1] points out that "A suspect may give a large response [...] not because he is guilty of robbing [...] but because he has robbed [in] other [...] places". Later Backster labeled the phenomenon as the "Outside Issue Factor", a factor that in some instances has a "Dampening (or Super Dampening) effect" that may suppress the examinee's reactivity to the relevant (in the case of a guilty examinee) or to the comparison (in the case of a truthful examinee) questions", [2] resulting in an inconclusive chart.

While unanimous about the phenomenon, scholars disagree about its effect. Some "suggest negligible or nonexistent consequence" [3] that result in noisy and erratic charts. On the other hand, Honts et al. [4] found that its presence "had a strong differential impact on the participants who were innocent of the tested issue, and it dramatically moved their scores toward deception. The impact of an outside issue on the guilty was minimal".

It should be emphasized that the mere existence of an outside issue does not necessary have to contaminate the examinee's charts. So far there is no research indicating who might be possibly contaminated, but it seems that educated examinees, who are more sensitive to nuances (which eventually enhance responsiveness), are more probable candidates for contamination by an outside issue. 


\section{Remedies}

Reid [5] suggested "the control questioning technique is of particular value [...]. With this advanced technique the subject is informed that, except for the general control question, the relevant test questions will be confined to the particular issue under investigation, the theory that this instruction will result in a subsidence of the disturbing effect of any other possible offenses". Yet, Reid himself raised some doubts around his solution: "however, some truthful subjects will continue to produce generally disturbed polygraph records". [6]

Backster incorporated into his Zone Comparison test format two symptomatic questions aimed toward isolating the possible existence of an outside issue which may suppress the examinee's responses to the relevant or comparison questions. Backster assumed that "With 'super-dampening' the only expected reaction to occur is to the symptomatic question under discussion". [7]

While the symptomatic questions were designed as a mean of detecting the existence of an outside issue and as such they were not analyzed or scored, "some US Government agencies such as the Army CID and the Naval Investigative Service went as far as using them as comparison questions to the relevant questions". [8]

As for the effectiveness of Backster's remedy, scholars' opinions are diverse. On one hand Capps et al. found that their "research provides evidence to substantiate Backster's claim that the inclusion of symptomatic questions in the control question polygraph examination significantly reduces the inconclusive calls made by the examiner. The numbers of inconclusive calls were reduced by two-thirds, exactly as Backster predicted. This study found, as Backster did, that the symptomatics do make a significant difference in terms of alleviating inconclusive results". [9] On the other hand Honts et al. concluded that the "(Symptomatic) test questions about possible outside issues were ineffective in detecting the presence of the outside issue". [10] Krapohl et al. as well as Honts found that "reactions to symptomatic questions had no correlation with the strength of polygraph scores in either the manual 7-position scorings or the automated ROSS. The predicted super-dampening effect was not found". [11]

As mentioned, the symptomatic question's purpose is to identify the existence of an outside issue. But when the examinee - who is not familiar with the purpose of the question - is asked "Are you completely convinced that I will not ask you a question during this chart that has not already been reviewed?" (Matte, p. 198) or "Is there something else you are afraid I will ask you a question about, even though I told you I would not?" he or she may believe that the actual question being asked is "Do you 
trust / believe me or not?". Consequently, when presented with the symptomatic questions, many examinees spontaneously respond with "I have believed you until now...". And so, if the examinee identifies the symptomatic question as a trust question, then her/his response merely reflects her/his trust or mistrust for the examiner rather than presence of an outside issue. However, a significant reaction to the symptomatic question indicative of examinee mistrust of the examiner requires Backster's application of his 8-Reaction Combination Guide (Matte, pp. 199, 281, 292, 325), designed to establish the examinee's trust in order to avoid the interference of an outside issue.

\section{Solution}

As in many other aspects of polygraphy, there is no magic formula or solution (or in this case, a magic question) here, but rather a thorough painstaking pretest to increase the chances of being told of an outside issue as well as establishing good rapport and trust.

Although most examinees may have an outside issue that may contaminate their responses, surfacing it in the pretest may turn it from a non-issue to an outside issue. For this reason, it should only be touched briefly without further questioning. The examiner should ask questions regarding past involvement but once the examinee denies it, no further questions should be asked. Only upon concluding at least two charts that are erratic and noisy, and allow the suspicion of being contaminated, should the examiner commence a thorough in-depth questioning. To demonstrate the effect of contamination, the examinee should be informed that a grain of salt is enough to prevent water from boiling at $100^{\circ} \mathrm{C}$, so she/he should rather tell what was on her/his mind upon hearing the relevant question. Once the examinee has opened and shared her/his concerns, the examiner should proceed to the successive charts adding the prefix "other than what you have told me..." to the question. If the examinee does not add anything, the examiner should assure her/him that $s /$ he has no interest in other violations or wrongdoing but only the issue in hand, and then proceed to the next chart. If the charts are still noisy the examinee should be confronted and be told that unless she/he cooperates, the examiner won't be able to reach a conclusion, which usually makes truthful examinees cooperate with the examiner and share their conscience. If no further information is provided and the charts are inconclusive, it is strongly suggested to have the examinee re-tested on a later day by another examiner. The examinee should be informed that because the results are not significant in some of the questions, the examiner would like to submit the examinee to an additional test. In such a retest, the comparison questions 
should be replaced. If the examiner has used a nonexclusive comparison question (without a time bar), it should be replaced with an exclusive comparison question which excludes the current violation by time and/or place. The retest should consist of at least two charts. A retest usually produces clearer charts, which allows the examiner to reach a decisive conclusion.

\section{List of contaminating factors}

\begin{tabular}{|c|c|}
\hline Factor source & Solution \\
\hline \multicolumn{2}{|l|}{ Cognitive } \\
\hline anger & $\begin{array}{l}\text { Ventilation: discuss and let it surface and } \\
\text { "steam out". }\end{array}$ \\
\hline concealment of another crime & Discuss and try to obtain the information. \\
\hline concealment of relevant information & Discuss and try to obtain the information. \\
\hline fear of consequences & Nothing to be done. \\
\hline $\begin{array}{l}\text { fear of the unknown ("It's my first time and it } \\
\text { seems like an electric chair.") }\end{array}$ & Explain the instrument/physics in length. \\
\hline $\begin{array}{l}\text { fear of the examiner's lack of objectivity: per- } \\
\text { ceiving the examiner as an adversary }\end{array}$ & $\begin{array}{l}\text { Assure your objectivity and avoid convinc- } \\
\text { ing. In an event of an Inconclusive finding, } \\
\text { consider the use of Quadri-Track ZCT that } \\
\text { addresses Fear of Error. }\end{array}$ \\
\hline $\begin{array}{l}\text { disbelief in examiner professionalism: this } \\
\text { may be his failure }\end{array}$ & $\begin{array}{l}\text { Assure your professionalism and avoid con- } \\
\text { vincing. In an event of an Inconclusive find- } \\
\text { ing, consider the use of Quadri-Track ZCT } \\
\text { that addresses Fear of Error. }\end{array}$ \\
\hline $\begin{array}{l}\text { disbelief in the polygraph - the test does not } \\
\text { pose any treat of detection }\end{array}$ & Explain the instrument/physics in length. \\
\hline $\begin{array}{l}\text { inadequate comparison questions - either } \\
\text { poor phrasing or improper introduction }\end{array}$ & Rephrase. \\
\hline $\begin{array}{l}\text { ineffective RQ or CQ - double meaning, too } \\
\text { long, unclear phrasing }\end{array}$ & Rephrase. \\
\hline lack of education & Explain in a very simple manner. \\
\hline $\begin{array}{l}\text { loss of control ("It's not in my hands but in } \\
\text { the hands of a machine.") }\end{array}$ & It's the examiner not the machine. \\
\hline mental abnormality & Avoid testing! \\
\hline $\begin{array}{l}\text { misunderstanding of the RQ or CQ - lan- } \\
\text { guage and/or the examinee's limited cognitive } \\
\text { capability being an obstacle; lack of education } \\
\text { causing misunderstanding of questions }\end{array}$ & Explain in a very simple manner. \\
\hline
\end{tabular}




\begin{tabular}{|c|c|}
\hline $\begin{array}{l}\text { outside issues: distraction due to the exami- } \\
\text { nee's mind being focused on an unrelated } \\
\text { matter (family, work, etc.) }\end{array}$ & $\begin{array}{l}\text { Discuss and try to obtain the information. } \\
\text { Establish examinee's trust - no unreviewed } \\
\text { questions will be asked. }\end{array}$ \\
\hline $\begin{array}{l}\text { excessive anxiety caused by the possibility of } \\
\text { failure ("I always fail tests.") }\end{array}$ & $\begin{array}{l}\text { Ventilation: discuss and let it surface and } \\
\text { "steam out". }\end{array}$ \\
\hline $\begin{array}{l}\text { prejudice against polygraph (rumors, online } \\
\text { gossip) }\end{array}$ & Explain the instrument/physics in length. \\
\hline $\begin{array}{l}\text { prior tests (either mistaken results or bad ex- } \\
\text { perience) }\end{array}$ & Reassure your professionalism. \\
\hline rationalization and self-deceit & $\begin{array}{l}\text { Explaining the instrument/physics in length } \\
\text { create a fear of consequences. }\end{array}$ \\
\hline $\begin{array}{l}\text { resentment ("A machine will determine my } \\
\text { truthfulness.") }\end{array}$ & It is the examiner not the machine. \\
\hline \multicolumn{2}{|l|}{ Emotional } \\
\hline excessive interrogation prior to the test & Don't test close to any other questioning. \\
\hline extreme emotional tension and nervousness & Try to relax and establish rapport. \\
\hline $\begin{array}{l}\text { extreme emotional tension and nervousness } \\
\text { regardless of the test scope }\end{array}$ & Discuss and try to obtain the information. \\
\hline guilt complex & Discuss and try to obtain the information. \\
\hline $\begin{array}{l}\text { guilty feeling of being responsible for the oc- } \\
\text { currence }\end{array}$ & Discuss and try to obtain the information. \\
\hline humiliation (“It's a test for criminals.") & $\begin{array}{l}\text { Show understanding and explain that more } \\
\text { innocent than guilty takes the test. }\end{array}$ \\
\hline $\begin{array}{l}\text { induction - transferring reactions from one } \\
\text { relevant question to the others }\end{array}$ & $\begin{array}{l}\text { If MGQT separate test to numerous single } \\
\text { issues. }\end{array}$ \\
\hline \begin{tabular}{|l|l} 
insufficient time to digest the test &
\end{tabular} & Delay the test to a later hour/date. \\
\hline $\begin{array}{l}\text { insult ("After so many years they still doubt } \\
\text { my honesty?") }\end{array}$ & Discuss and try to obtain the information. \\
\hline invasion ("You are penetrating my soul.") & Discuss and try to obtain the information. \\
\hline $\begin{array}{l}\text { lack of proper incubation: test given without } \\
\text { any proper prior notification }\end{array}$ & Delay the test to a later hour/date. \\
\hline $\begin{array}{l}\text { lack of concern over the possibility of detec- } \\
\text { tion }\end{array}$ & Try to create concern. \\
\hline shame ("They all believe that I did it.") & This is your chance to prove otherwise. \\
\hline $\begin{array}{l}\text { trauma in case of a victim, eyewitness or sus- } \\
\text { pect (e.g. a parent) }\end{array}$ & Consider a confirmatory type test. \\
\hline \multicolumn{2}{|l|}{ Physical } \\
\hline adrenal exhaustion & Delay the test to a later hour/date. \\
\hline drug influence - sleepy, unfocused, drowsy & Delay the test to a later hour/date. \\
\hline
\end{tabular}




\begin{tabular}{|l|l|}
\hline $\begin{array}{l}\text { fatigue - lack of proper rest prior to the test, } \\
\text { hard to focus, falling asleep, fighting sleep }\end{array}$ & Delay the test to a later hour/date. \\
\hline $\begin{array}{l}\text { an illness effecting body functions and mental } \\
\text { attentiveness }\end{array}$ & Delay the test to a later hour/date. \\
\hline physical obstacles (blindness, deafness, etc.) & $\begin{array}{l}\text { Depending on the obstacle, consider not test- } \\
\text { ing } .\end{array}$ \\
\hline $\begin{array}{l}\text { physical discomfort caused by room tempera- } \\
\text { ture, air flow, noise, uncomfortable chair, bad } \\
\text { smells, etc. }\end{array}$ & $\begin{array}{l}\text { Ask for the source and try to solve the prob- } \\
\text { lem. }\end{array}$ \\
\hline
\end{tabular}

\section{References}

[1] Trovillo Paul Y. (1939), A history of lie detection. Journal of Criminal Law, Criminology and Police Science, 29, pp. 848-881, Reprinted in Polygraph 1972, 1 (2), pp. 46-74, and 1(3), pp. 151-160.

[2] Matte J.A., Forensic Psychophysiology Using The Polygraph, J.A.M Publications, Williamsville NY, 1996, pp. 41-42, 199, 203-205, 278, 281, 292, 325, 328-342.

[3] Krapohl D., Sturm S., (2002), "Superdampening Concept”, Terminology Reference for The Science of Psychophysiological Detection of Deception, Polygraph 31 (3), p. 221.

[4] Honts C.R., Amato S.L., Gordon A. (2004), Validity of outside-issue questions in the control question test, The Journal of General Psychology 131 (1), pp. 53-76.

[5] Reid J.E., Inbau F.E., Truth and Deception, William \& Wilkins, Baltimore 1977, p. 224.

[6] Ibidem, pp. 41-42.

[7] Backster C., A Response to Kraphol \& Ryan's "Belated Look at Symptomatic Questions", Polygraph, 30 (3), pp. 213-215.

[8] Capps M.H, Knill B.L., Evans R.K. (1993), Effectiveness of the symptomatic questions, Polygraph, 22 (4), pp. 285-298.

[9] Ibidem, p. 294.

[10] Ibidem, p. 53.

[11] Krapohl D.J., Ryan A.H. (2001), A belated look at symptomatic questions, Polygraph 30 (3), p. 206. 